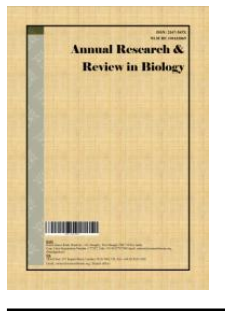

\title{
Agronomic Behavior of Six Saladette Tomato Hybrids Grown under Shade Mesh
}

\author{
María del Pilar Marín Cortez ${ }^{1}$ and Neymar Camposeco Montejo ${ }^{2^{\star}}$ \\ ${ }^{1}$ Departament of Horticulture, Universidad Autónoma Agraria Antonio Narro, Calzada Antonio Narro \\ 1923, Buenavista, Saltillo CP, 25315, Coahuila, México. \\ ${ }^{2}$ Department of Plant Breeding, Seed Technology Training and Development Center, Universidad \\ Autónoma Agraria Antonio Narro, Calzada Antonio Narro 1923, Buenavista, Saltillo CP, 25315, \\ Coahuila, México.
}

Authors' contributions

This work was carried out in collaboration between both authors. Authors NCM and MPMC designed the study, performed the statistical analysis, wrote the protocol and wrote the first draft of the manuscript. Author NCM managed the analyzes of the study. Author MPMC managed the literature searches. Both authors read and approved the final manuscript.

Article Information

DOI: $10.9734 / A R R B / 2020 / v 35 i 830258$

Editor(s):

(1) Dr. Manikant Tripathi, Dr. Ram Manohar Lohia Avadh University, India.

Reviewers:

(1) Farrukh Azeem, Government College University Faisalabad (GCUF), Pakistan.

(2) Fernando Antonio Sernaqué Auccahuasi, César Vallejo University, Peru.

(3) Navin Pradhan, W.B.A.S. (Research) Scientist Potato and Maize Research Station and Krishi Bhawan Midnapore, India.

Complete Peer review History: http://www.sdiarticle4.com/review-history/59644

Original Research Article

Received 27 May 2020

Accepted 02 August 2020

Published 10 August 2020

\begin{abstract}
Aims: The objective was to evaluate six indeterminate saladette tomato hybrids in Southeast, Coahuila, Mexico. Under shade house covered with anti-aphid mesh, to determine their performance, commercial quality and adaptability.

Study Design: The experimental design used in each test was completely randomized model with six treatments and three repetitions each. The treatments were hybrids Lubino were Lubino $F_{1}$, Zopilote $F_{1}$, Sahariana $F_{1}$, Raptor $F_{1}$, Quetzal $F_{1}$ and RTF-713172 $F_{1}$.

Place and Duration of Study: The site was Parras Valley Tomatoes in Parras, Coahuila, México. During april to November 2017.

Methodology: The distance between the lines were $1.80 \mathrm{~m}$, between the plantpots $36 \mathrm{~cm}$ and two plants per plantpots, with approximately 30,000 plants per hectare calculated. The genotypes used were Lubino $F_{1}$, Zopilote $F_{1}$, Sahariana $F_{1}$, Raptor $F_{1}$, Quetzal $F_{1}$ and RTF-713172 $F_{1}$. The following
\end{abstract}


agronomic characteristics were evaluates: yield, total number of fruits, average fruit weight, number of fruits per bunch, length between clusters, length of internodes, main stem thickness and commercial quality of fruit.

Results: The results indicate that the highest yielding hybrid was Zopilote with $4.3 \mathrm{~kg} \mathrm{plant}^{-1}$, followed by Saharan, the average weight of the product obtained best in Saharan and Quetzal with 122.33 and $118.33 \mathrm{~g}$ respectively, the most compact variety was Zopilote due to the shorter distance between bunches, contrary to what was demonstrated by Lubino.

Conclusion: The best variety for the Southeast of Coahuila is Zopilote $F_{1}$, due to its higher yield and for being a compact plant.

Keywords: Yield; commercial quality; climate change; Solanum lycopersicum L.

\section{ABBREVIATIONS}

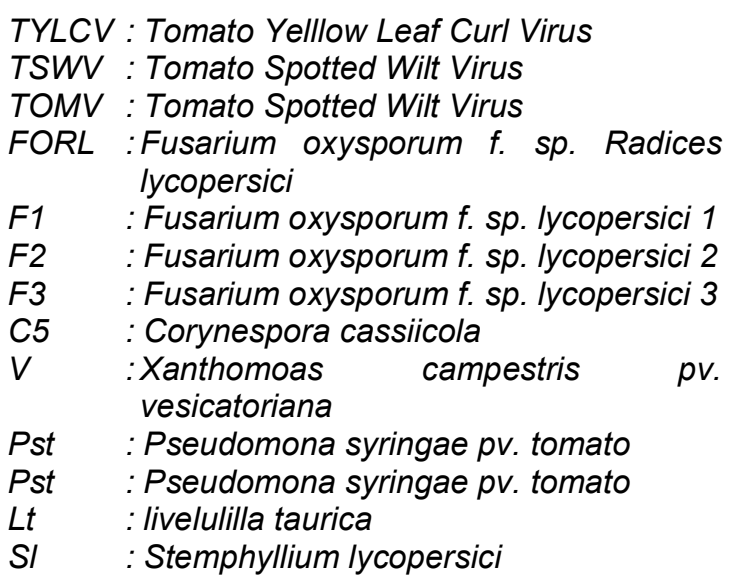

\section{INTRODUCTION}

Tomato is one of the most important vegetables in Mexico, in 2018 more than 50 thousand hectares were planted, with an average production of $102 \mathrm{t} \mathrm{ha}^{-1}$ with production of 3.5 million tons and commercial value of more than 25500 million of pesos, so it represents $22.5 \%$ of the production among vegetables and contributes $3.5 \%$ of the PIB national agricultural [1]. Numbers by which Mexico provides $25 \%$ of the international market, with the United States and Canada being the main export destinations, with $90 \%$ and $65 \%$ of imports from each country, respectively [1]. But despite its importance, the crop faces problems and challenges to solve in the national territory, one of these problems is the current global climate change and the repercussions it will have in the future, on food production. FAO data indicates that global climate change is one of the greatest challenges facing humanity, since it represents an additional pressure on the environment, pressures ranging from changing weather conditions, to the increase in the level of the seas [2]. What will increase the risk of catastrophic floods, and other effects of global scale, which threaten world food production. These predictions indicate that the effects of climate change will worsen the living conditions of farmers, ranchers, fishermen, etc., causing an increase in hunger and malnutrition. Extreme climatic episodes are increasingly frequent and intense; therefore, the effect will have a negative impact on the availability and access to food, its stability and use [2].

The impacts of climate change are such that humans, plants, livestock and fisheries will be exposed to new pests and diseases, which will imply new risks for food security, food safety and human health. This implies a rapid adaptation to said changes, therefore, a more efficient use of soil-water-environment resources will have to be made. In the agricultural sector, more effective irrigation systems should be developed, superior improved plant varieties, better management of agricultural soils and innovating with cultivation techniques that allow the optimization of resources, in order to minimize the negative effects [3].

The problems that derive from global climate change today, suppose the need to create, develop and implement new cultivation techniques and technologies that allow reducing the negative impact on agricultural activities and at the same time satisfy the needs of farmers and consumers [4], [5]. In order to face these problems, trying the new hybrids developed by the seed companies or institutions, from a local and regional point of view, has become an activity increasingly practiced by farmers, whose purpose is to find the ideal variety for the area of production and for the environment under which it develops [6,7]. Because hybrids respond differently in production systems, geographic areas, and environments, since they show varied productivity $[8,9]$. Previous studies on tomato indicate that testing hybrids or varieties in the different production regions allows determining 
their adaptability, yield, tolerance to pests and diseases in a given region [10], and that the highest yielding varieties are those of greater attraction by farmers, so going ahead with the tests is relevant, since it allows making recommendations and suggestions to the producer [11], in addition to the tests it can also determine if it is possible to use an $F_{2}$ for commercial production [12]. Similar studies have been carried out on pepper crops [13,14], cucumber [15] and melon [16]. Due to the foregoing challenges posed by global climate change, it was proposed to investigate the performance of six indeterminate saladette tomato hybrids under shady house conditions covered with anti-aphid mesh in Southeast Coahuila.

\section{MATERIALS AND METHODS}

\subsection{Description of the Experimental Site}

The experiment was conducted in SpringSummer 2017 at the Parras Valley Tomatoes in Parras de la Fuente, Coahuila, Mexico, located at $25^{\circ} 26^{\prime \prime} 13^{\prime} \mathrm{N}$ and $101,11^{\prime \prime} 0^{\prime}, \mathrm{W}$, with an average annual temperature of $14-18^{\circ} \mathrm{C}$ and an average annual precipitation of $490 \mathrm{~mm}$. The work was carried out with the support of the company's phenology department.

\subsection{Genetic Materials}

The genetic material tested was Lubino $F_{1}$ Nirit Seeds, which is precocious, with fruits of sizes $L$ and $\mathrm{XL}$, resistance to TYLCV, TSWV, ToMV, V, F1, F2, F3 and C5. Zopilote $F_{1}$ BHN Seeds of strong and healthy plant, with abundant roots, vigorous stem, short internodes, leaves of medium size, with fruits $L$ and $X L$, of wall and thick cuticle, with excellent firmness and resistance to F2, ToMV, TSWV. Sahariana $F_{1}$ Syngenta Seeds with strong, vigorous and balanced plant for long cycles, high productivity, with $\mathrm{XL}$ sizes, excellent for areas of high luminosity and low relative humidity, as well as high resistance to $\mathrm{V}$, ToMV, TSWV, F3, Forl, Lt, $\mathrm{SI}$, and intermediate resistance to Meloydogine. Raptor $F_{1}$ BHN Seeds with good vigor, uniformity and health, medium-sized leaves, good vegetative / reproductive balance, fruits of sizes $\mathrm{L}$ and $\mathrm{XL}$, as well as resistance to $\mathrm{V}, \mathrm{F} 2$, ToMV, TSWV, TYLCV, Pst. Quetzal $F_{1}$ BHN Seeds with a strong plant, thick stems and short internodes, with wide adaptability to hot climates, fruits of sizes $L$ and $X L$, resistance to $V, F 2$, ToMV, TSWV, TYLCV. RTF-713172 $\mathrm{F}_{1}$.

\subsection{Establishment under Shade House and Crop Management}

The hybrid seedlings were assembled at the Protoplaneta seedbed located in San Luis Potosí, Mexico, and sent to the Parras Valley Tomatoes. The transplant was performed the last week of July 2017, in pots of white polyethylene bags with a capacity of 20 liters, which were filled with $100 \%$ perlite as an inert substrate, $\mathrm{pH} 7$, particle size $0.2-0.5 \mathrm{~mm}$, which is cheap and used commercially by the agricultural company. Once the substrate was moistened, the transplant was performed. Two plants per pot were placed at a depth of approximately 8 to 10 $\mathrm{cm}$, so that the root ball was completely covered. The experiment was conducted under a completely randomized experimental arrangement with six treatments ( $F_{1}$ hybrids) and three repetitions each, with 6 useful plants with complete competition in each experimental unit, with a distance between rows of $1.8 \mathrm{~m}$ and between plantpots of $36 \mathrm{~cm}$ and two plants per plantpots, giving. As a result, a planting density of approximately 30000 plants per hectare, the shade house cover where the experiment was carried out is made of glass-colored anti-aphid mesh with $20 \%$ shade ( $40 \times 25$ mesh).

The nutrition of the crop was based on that used by the company, which is based on the nutrient solution proposed by Steiner (1966), modified according to the phenological stage of the crop and the chemical composition of the irrigation water used. The nutritive solution was supplied in percentage according to the growth stage of the crop, which consisted of applying $50 \%$ four days after transplanting, $75 \% 20$ days after transplanting, and once flowering and mooring were started, it was supplied $100 \%$, the drainage used was that recommended by the company's grower and is $10 \%$. For pest control, weekly applications of organic products based on chili, garlic and onion extract were made, in addition to neem extract and roma $®$ soap, when the incidence was higher, synthetic chemical products such as Spirotetramat at $15.3 \%$ were used, Spiromesifen at $23.1 \%$, Imidacloprid $17 \%$ + cylfutrin $12 \%$ at the rate of $1 \mathrm{ml}^{-\mathrm{L}^{-1}}$.

\subsection{Determination of Evaluated Variables}

The total yield in kilograms per plant (kg. plant ${ }^{-1}$ ) was estimated by harvesting the fruits of each plant that were harvested for ten weeks (75 to 150 days after transplanting), which were weighed on a Sartorius model TS 1352Q37 
digital precision scale, to then calculate the yield per hectare $\left(\mathrm{t} \mathrm{ha}^{-1}\right)$. The total number of fruits (TNF) harvested in each plant was counted, considering the total sum of the harvests. The average fruit weight (AFW) was calculated by dividing the total fruit weight by the total number of fruits per plant, the number of fruits per bunch (NFB), accounting for the amount of fruits harvested in each bunch. The length between clusters (LBC) and length of internodes (LI) were estimated using a tape measure graduated in $\mathrm{cm}$, while the main stem thickness (MST) was estimated with a digital vernier of the Autotec $®$ brand graduated in $\mathrm{mm}$ at $5 \mathrm{~cm}$ from the base of the stem.

\subsection{Determination of Commercial Quality}

To determine the commercial quality of the fruits, they were weighed individually on a Sartorius model TS 1352Q37 digital precision weighing machine, and it was carried out in four intermediate harvests, the first one 85 days after transplanting (DAT), the second at 106, the third at 127 and the last at 148 DAT. From the data obtained, the percentage was calculated according to its commercial classification, and it was carried out dividing the kilograms of each commercial quality by the total kilograms harvested and multiplied by one hundred, which was used to extrapolate and calculate the commercial yield in tons per hectare. In each treatment (kg plant ${ }^{-1}$ * total number of plants per hectare), which was estimated by multiplying the classification percentage (in unit) by the calculated total tons harvested and expressed as follows.

$$
\begin{aligned}
& \% \text { classification }=\frac{\mathrm{kg} . \text { of each } \text { classification }}{\text { total } \mathrm{kg} \text {. }} * 100 \\
& \text { Tons of classification calculated } \\
& =\% \text { classificaction (unit) } \\
& \text { * total tons calculated }
\end{aligned}
$$

\subsection{Statistic Analysis}

Statistical analysis was performed with the SAS Version 9.1 program. The experimental design and statistical analysis was with the completely randomized model with six treatments and three repetitions each, with comparison of Tukey means (Tukeys.05).

\section{RESULTS AND DISCUSSION}

\subsection{Yield and Components Yield}

The analysis of variance showed significant statistical differences between hybrids for all the variables evaluated (ANOVA $\leq .05$ ). The Tukey $\leq .05$ mean comparison test (Fig. 1) indicates that the hybrid Zopilote $F_{1}$ had the highest performance with $4.3 \mathrm{~kg}_{\text {plant }}{ }^{-1}$ or $129.14 \mathrm{t} \mathrm{ha}^{-1}$, followed by Sahariana and RTF-713172 with 3.67 and $3.33 \mathrm{~kg} \mathrm{plant}^{-1}$ and 110.18 and 100.01 $\mathrm{t} \mathrm{ha}^{-1}$ respectively, said numbers indicate that Zopilote outperformed Lubino in $108 \%$, Quetzal in $88.3 \%$ and Raptor in $71.7 \%$. The average fruit weight was higher in the Saharan and Quetzal hybrid with 122.33 and $118.33 \mathrm{~g}$, respectively, followed by Zopilote and Lubino in average weight. Regarding the number of fruits per bunch, a similar behavior was observed in five of the hybrids, with the exception of Quetzal, which was the one with the lowest number of fruits per bunch. The different response that the hybrids showed, was probably due to the genetic load of each one, which was expressed in a phenotype with particular characteristics of each cultivar, characteristics that make it adaptable, not very adaptable or not adaptable to a production system, determined geographical area and crop management. Furthermore, it is influenced by the response of hybrids over time, mainly due to environmental changes from one year to another [17], since each variety shows variations in performance, due to its individual adaptability to specific environmental conditions $[18,11]$, an example of this is that in the Amazon pepper is better if grown in the open field than in a greenhouse [19]. In addition to the specific adaptation of the genotypes to the different exposed environments [8]. However, it is also important to consider adaptability and tolerance to viruses, pests and diseases [16], as well las the sensory quality of the fruits produced, since it changes between hybrids, and this quality determines the target market and its final price in the market [20].

\subsection{Agronomic Performance Indicators}

Some agronomic performance indicators, such as the length between clusters, were similar in five hybrids (Table 1), with the exception of Zopilote, which was the variety with the shortest distance between clusters, which was $30 \%$ less than the rest, which is to highlight and take into account, since producers generally seek tomato plants with short internodes and compact size for concentrated productions, which allow better management of the plant and crops in general. While the length of internodes, Lubino stood out with $6.74 \mathrm{~cm}$ with the longest length between clusters. The largest stem thickness was obtained by Lubino with $9.13 \mathrm{~mm}$, followed by 

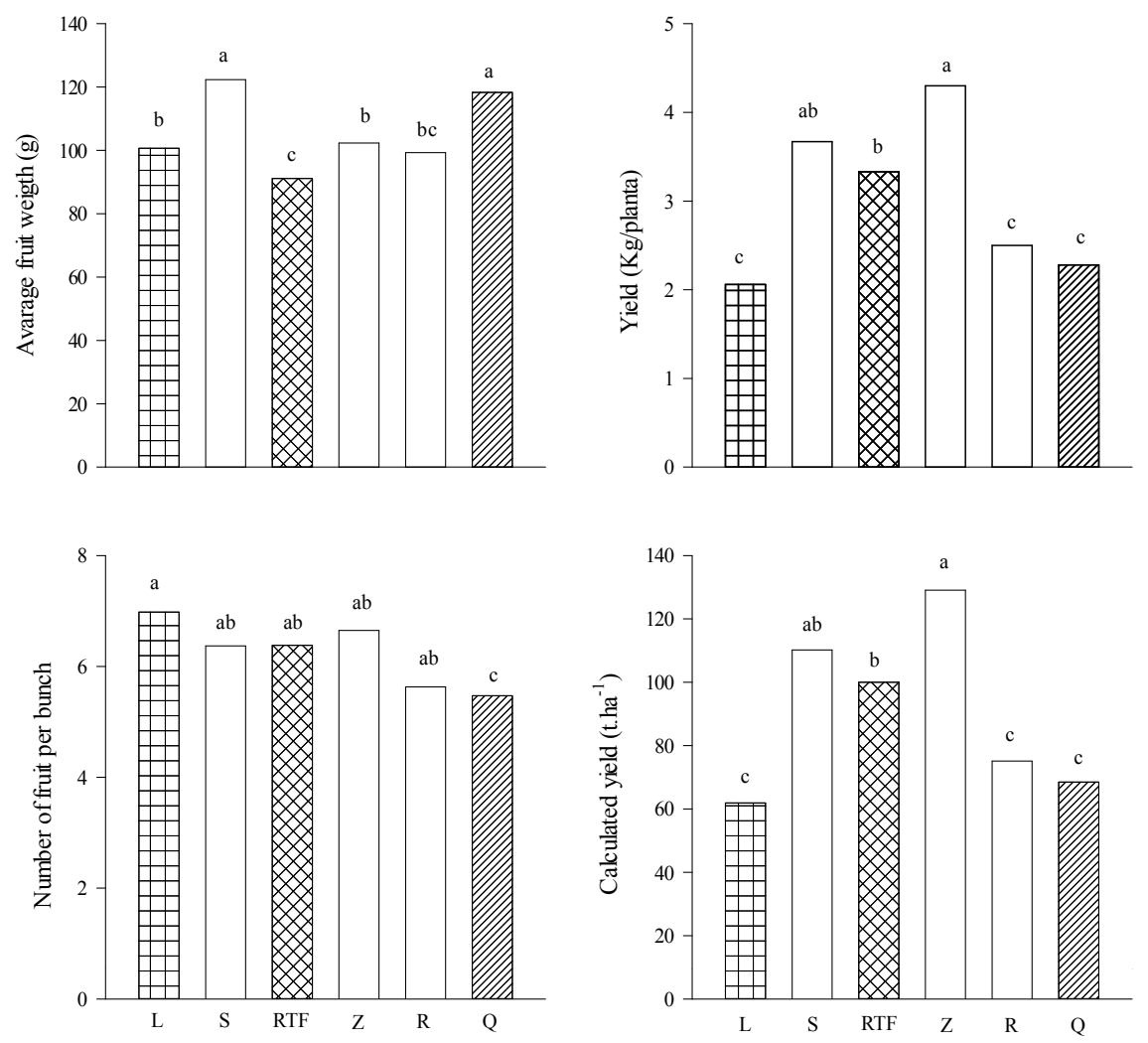

Fig. 1. Yield averages and components evaluated in six saladette tomato hybrids evaluated in Parras de la Fuente, Coahuila, México,L= Lubino $F_{1}, S=$ Sahariana $F_{1}, R T F=R T F-713172 F_{1}, Z=$ Zopilote $F_{1}, R=$ Raptor $F_{1}$ y $Q=$ quetzal $F_{1}$

Raptor and Quetzal with 9.04 and $8.68 \mathrm{~mm}$, respectively. These phenotypic changes are the result of the genotypes' response to the environment in which they develop $[8,10]$. In addition to the fact that crop management also defines and determines their productivity in the long term [14]. Hybrids would probably have had a different behavior if they had been tested under greenhouse or open field conditions.

\subsection{Commercial Quality of the Fruit}

Another parameter that determines the selection of a variety as good and ideal for cultivation in a certain area and under a certain condition, is the commercial quality of the fruit (Table 2). When commercial quality was expressed as a percentage (\%), the variety Zopilote stood out in fruits of size XXL with $3.17 \%$, followed by Sahariana with $2.62 \%$, in sizes XL Raptor stands out with $15 \%$, followed by Zopilote and Saharan with 10.3 and $9 \%$, respectively, while the highest percentage of $L$ sizes was found in
RTF-713172 and Quetzal with 37.38 and 36.92 $\%$, respectively, regarding size $M$ Lubino stood out with $57 \%$, followed by Zopilote and Sahariana with $54 \%$, hybrids The ones that had the highest percentage of small fruits were Quetzal and RTF-713172, which is little or undesirable for the producer.

When the percentage of commercial classification of each variety was expressed and extrapolated to tons per hectare (Fig. 2) shown above. It was found that the highest production of $\mathrm{XXL}$ and $\mathrm{XL}$ sizes were presented by vulture with 4.1 and $13.32 \mathrm{t} \mathrm{ha}^{-1}$ respectively, followed by Sahariana and Raptor, while the highest percentage of $\mathrm{L}$ sizes had RTF-713172 with $37.39 \mathrm{t} \mathrm{ha}^{-1}$, followed by Zopilote and Quetzal with 27.6 and $25.2 \mathrm{t} \mathrm{ha}^{-1}$, respectively, regarding fruits of size $M$, Zopilote also stood out with $70.31 \mathrm{t} \mathrm{ha}^{-1}$, followed by Sahariana with $60.3 \mathrm{t}$ $\mathrm{ha}^{-1}$. The hybrids that produced the smallest fruits were RTF-713172 and Sahariana. According to the results found, it is inferred that 
Table 1. Averages of agronomic performance indicators in six saladette tomato hybrids evaluated in Parras de la Fuente, Coahuila, México

\begin{tabular}{|c|c|c|c|}
\hline Hybrids & LBC (cm) & LI (cm) & MST (mm) \\
\hline Lubino $\mathrm{F}_{1}$ & $33.12 a^{\alpha}$ & $6.74 \mathrm{a}$ & $9.13 \mathrm{a}$ \\
\hline Sahariana $F_{1}$ & $31.66 \mathrm{a}$ & $5.23 \mathrm{~b}$ & $7.63 \mathrm{bc}$ \\
\hline RFT-713172 $F_{1}$ & $31.74 \mathrm{a}$ & $5.42 \mathrm{~b}$ & $7.46 \mathrm{c}$ \\
\hline Zopilote $F_{1}$ & $25.67 b$ & $5.05 \mathrm{~b}$ & $8.24 a b c$ \\
\hline Raptor $F_{1}$ & $30.76 a b$ & $5.60 \mathrm{~b}$ & $9.04 a b$ \\
\hline Quetzal $F_{1}$ & $32.12 \mathrm{a}$ & $5.72 b$ & $8.68 \mathrm{abc}$ \\
\hline Significant & $* *$ & $* *$ & $* *$ \\
\hline CV $(\%)$ & 5.97 & 6.099 & 6.07 \\
\hline
\end{tabular}

Table 2. Commercial quality expressed as a percentage of six saladette-type tomato hybrids evaluated in Parras de la Fuente, Coahuila, México

\begin{tabular}{llllll}
\hline & & \multicolumn{1}{c}{$(\%)$} \\
\hline Hybrids & Jumbo $(\mathbf{X X L})$ & Extra large $\mathbf{( X L )}$ & Large $(\mathbf{L})$ & (Medium) $\mathbf{M}$ & Small $(\mathbf{S})$ \\
\hline Lubino $\mathrm{F}_{1}$ & 0.00 & 0.33 & 20.39 & 56.91 & 22.37 \\
Sahariana $\mathrm{F}_{1}$ & 2.64 & 9.01 & 15.82 & 54.73 & 17.80 \\
RFT-713172 $\mathrm{F}_{1}$ & 0.55 & 8.84 & 37.38 & 28.55 & 24.68 \\
Zopilote $\mathrm{F}_{1}$ & 3.17 & 10.32 & 21.43 & 54.44 & 10.63 \\
Raptor $\mathrm{F}_{1}$ & 1.58 & 15.04 & 20.84 & 44.85 & 17.68 \\
Quetzal $\mathrm{F}_{1}$ & 1.64 & 5.37 & 36.92 & 30.84 & 25.23 \\
\hline
\end{tabular}

$X X L=$ Jumbo $(>150 \mathrm{~g}), X L=$ Extra large $(120-150 \mathrm{~g}), L=$ Large $(100-120 \mathrm{~g}), M=$ Medium $(80-100 \mathrm{~g}), S=$ Small
(60-80g)
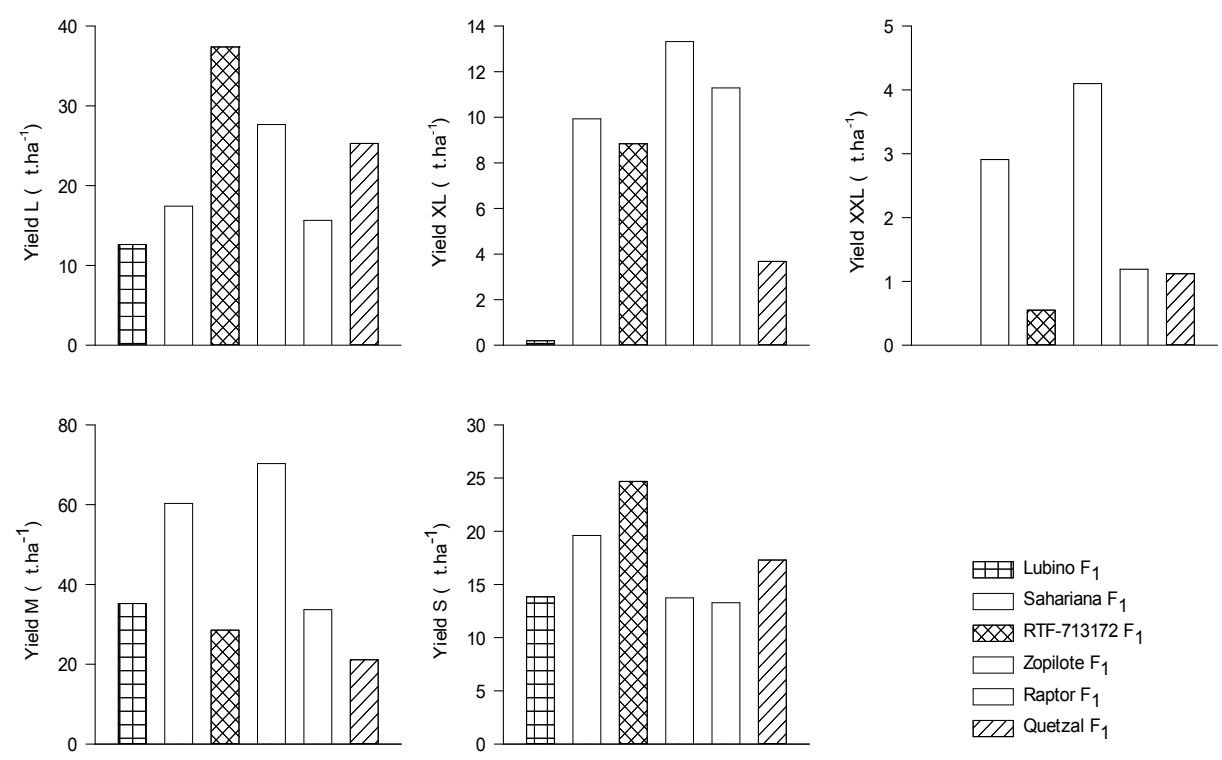

Fig. 2. Commercial quality in tons per hectare of six saladette-type tomato hybrids evaluated in Parras de la Fuente, Coahuila, México

the variety best adapted to the region and the cultivation system tested, as per global yield and its commercial classification, were Zopilote and RTF-713172 for generating a greater amount of extra large sized fruits, and large sized fruit, which are make the difference and are marketed at a better price in the national market and in the export market, however, Zopilote was also 
superior in medium-sized fruits and these are marketed at prices that are also acceptable. In relation to the aforementioned, [21] points out that the profitability of a greenhouse cultivation depends largely on obtaining high yields and the quality of its individual fruits per unit area, in addition to the harvest time.

\section{CONCLUSION}

For the Southeast region of Coahuila, of the hybrids evaluated, Zopilote $F_{1}$ was the one that best adapted under the shade covered with antiaphid mesh and using $100 \%$ perlite as substrate, since it was a compact plant produced the highest total yield and commercial quality of fruits. As a consequence of current changes in the environment, it is recommended to carry out adaptability studies of the new varieties or hybrids that are offered in the market, since they allow determining, if a variety is adaptable to be cultivated in a certain region, based on the yield and the commercial quality of its fruits. However, it is also important to consider their adaptability or tolerance to viruses, pests and diseases.

\section{ACKNOWLEDGEMENTS}

Deep thanks to the engineer Isac Benjamin Vasquez Benitez and Parras Valley Tomatoes, for facilitating its facilities and field staff and to carry out the research work.

\section{COMPETING INTERESTS}

Authors have declared that no competing interests exist.

\section{REFERENCES}

1. SIAP Agri-food and fisheries information service.

Available:https://nube.siap.gob.mx/cierreag ricola/

Accessed. 2018.

2. FAO Food and Agriculture Organization of the United Nations.

Available:http://www.fao.org/climatechange/es/

Accessed. 2018.

3. ONU Unaited Nation Organization.

Available:http://www.un.org/es/sections/iss ues depth/climate-change/index.html Accessed. 2018.

4. López FAJ, Hernández CD. Climate change and agriculture, a review of the literature with an emphasis in América Latina. El Trimestre Económico. 2016;332: 459-496.

Available:http://dx.doi.org/10.20430/ete.v83 i332.231

5. Rivera HB, Aceves NLA, Arrieta RA, Juárez LJF, Méndez AM, Ramos AC. Evidence of climate change in the state of Tabasco during the period 1961-2010. Revista Mexicana de Ciencias Agrícolas. 2016;14:2645-2656.

Available:http://www.scielo.org.mx/pdf/rem exca/v7nspe14/2007-0934-remexca-7spe14-2645-en.pdf

6. Sierra JA, Grandette LM, Rodríguez MV, Tordecilla L, Rubiano JA, Ohoa AA. Evaluation of the susceptibility of eggplant hybrids to the mite Tetranychus Iudeni Zacher (Acari: Tetranichydae) in the department of Córdoba Colombia. III Latin American Congress of Acarology and VI Brazilian Symposium on Acarology. Pirenopolis, Goias, Brasil en; 2018.

Available:http://www.sibac.net.br/CD/resu mos/ResumoClac3Sibac6_0292.pdf

7. López EJ, Rodríguez JC, Huez LMA, Garza OS, Jiménez LJ, Leyva EEI. Cucumber production and quality (Cucumis sativus L.) under greenhouse conditions using two pruning systems. IDESIA. 2011;29(2):21-27.

Available:http://dx.doi.org/10.4067/S071834292011000200003

8. Ramírez VC, Neinhuis J. Evaluation of grwth and productivity of tomato (Solanum lycupersicum L.) under protected cultivation in three localities of Costa Rica. Tecnología en Marcha. 2012;25(1):3-15.

DOI: $10.18845 / \mathrm{tm} . v 25 \mathrm{i} 1.172$

9. Ahmad F, Khan O, Sarwar S, Hussain A, Ahmad S. Performance evaluation of tomato cultivars at high altitude. Sarhad J. Agric. 2007;23(3):581-585.

10. Amador LNA, Guzmán MDJ. Evaluation of five hybrids of tomato (Solanum esculentum Mill.) in Comarca el Tule Central del Municipio de Boaco of Juny to Augosto 2015. Graduate work. Universidad Nacional Agraria. Camoapa, Boaco, Nicaragua.

Available:http://repositorio.una.edu.ni/3263 /1/tnf30a481.pdf

11. Corella BRA, Soto OR, Escoboza GF Grimaldo JO, Huez LMA, Ortega NMM. Evaluation of two saladette-type tomato hybrids propagated by cuttings and by seed in a greenhouse for the Valle de 
Mexicali. XIV International Congress of Agricultural Sciences. 2011;143-147.

Available:http://www.agricultura.uson.mx/p ublicaciones/congresos/XIV\%20Congreso $\% 20$ Internacional/Evaluaci\%C3\%B3n\%20 de\%20dos\%20híbridos\%20de\%20tomate. pdf

12. Magaña LN, Peña LA, Sánchez del CF, Rodríguez PJE, Moreno PEC. Productive behavior of $F_{1}$ tomato hybrids and their populations $F_{2}$. Revista Fitotecnia Mexicana. 2013;36(4):371-379.

Available:http://www.scielo.org.mx/pdf/rfm/ v36n4/v36n4a2.pdf

13. Elizondo CE, Monge PJE. Evaluation of yield and quality of fivetheen genotypes of peppers (Capsicum annuum L.) grown under greehouse in Costa Rica. Tecnología en Marcha. 2017;30(4):3-14. DOI: 10.18845/tm.v30i4.3407

14. Sánchez del CF, Moreno PEC, Reséndiz MRC, Colinas LMT, Rodríguez PJE. Pepper production (Capsicum annuum L.) in short cycles. Agrociencia. 2017;51:437446.

Available:http://www.scielo.org.mx/pdf/agro /v51n4/1405-3195-agro-51-04-00437.pdf

15. Chacón PK, Monge PJE. Evaluation and quality evaluation of six cucumber genotypes (Cucumis sativus L.) grown under greenhouse in Costa Rica. Revista Colombiana de Ciencias Hortícolas. 2016;10(2):323-332.

Available:https://doi.org/10.17584/rcch.201 6v10i2.5069

16. Barrales HSM, Rivas SFJ, Guerrero RJC, Martínez HD, Serrano EA, Espinoza JG. Evaluation of eleven melon hybrids of the type cantaloupe and honey dew (Cucumis melo L.) and its response to the yellowing virus and severe dwarfism of cucurbits. Revista Biotecnia. 2012;14(1):25-32.
Available:https://biblat.unam.mx/hevila/Biot ecnia/2012/vol14/no1/4.pdf

17. Anikwe MAN, Agu JC, Ikenganyia EE. Agronomic evaluation of four exotic tropical varieties of watermelon (Citrullus lanatus L.) in two agro-enviroments in Nigeria. International Journal of Plant \& Soil Science. 2016;10(2)1-10.

DOI: $10.9734 / I J P S S / 2016 / 23298$

18. Tegelele A, Tesfaye $\mathrm{T}$. Evaluation of performance of tomato (Solanum esculentum) cultivars at Sekota North Eastern Ethiopia. Asian Journal of Agricultural Research. 2017;11(4):116119.

DOI: 10.3923/ajar.2017.116.119

19. Alemán PRD, Domínguez BJ, Rodríguez GY, Soria RS, Torres GR, Vargas BJC, Bravo MC, Alba R J. L. Morphological and productive indicators planted in greenhouses and open fields in the conditions of the Amazonia Ecuatoriana. Revista Centro Agrícola. 2008;45(1): 14-23.

Available:http://scielo.sld.cu/pdf/cag/v43n1/ cag10116.pdf

20. Ben AA, Lechichi G, Benyahya L, Ferchichi A. Evaluation of fruit quality traits of traditional varieties of tomato (Solanum lycupersicum) gorwn in Tunisia. African Journal of Food Science. 2013;7(10):350354.

Available:https//doi.org/10.5897/AJFS2013 .1067

21. Monge PJE. Effect of pruning and planting density on the yield and quality of the square pepper (Capsicum annuum L.) grown under greenhouse in Costa Rica. Tecnología en Marcha. 2015;29(2):125136.

Available:https://doi.org/10.18845/tm.v29i2 .2696

(0) 2020 Cortez and Montejo; This is an Open Access article distributed under the terms of the Creative Commons Attribution License (http://creativecommons.org/licenses/by/4.0), which permits unrestricted use, distribution, and reproduction in any medium, provided the original work is properly cited.

Peer-review history:

The peer review history for this paper can be accessed here: http://www.sdiarticle4.com/review-history/59644 